\title{
FAKTOR-FAKTOR YANG MEMPENGARUHI MINAT BELAJAR PENDIDIKAN AGAMA KRISTEN DI SEKOLAH
}

\author{
Nurmiati Marbun ${ }^{1}$, Lamtiur Pasaribu ${ }^{1 *)}$ \\ ${ }^{1}$ Prodi Pendidikan Agama Kristen, STT Injili Indonesia Medan
}

\begin{abstract}
Education is a necessity absolutely necessary for everyone, that without education, it is impossible for a person or society to experience a development towards advancing ideal, living a prosperous and happy life. Teaching and learning process activities in schools are important and core activities. School managed by an institution and regulates all potential to achieve educational goals. However, it's not enough to schools achieve it's educational goals. There is must be, a cooperation between schools and the community, also between parents and students is very important. However, it's not an easy thing to realize it, there are several factors can affect student's interest in learning Christian Education-outside factors and from within students.
\end{abstract}

Keywords: learning interesting, christian education, school

\begin{abstract}
Abstrak
Pendidikan merupakan suatu kebutuhan yang mutlak diperlukan bagi setiap insan manusia, sebab tanpa pendidikan sama sekali, maka mustahil bagi seorang pribadi atau sekelompok masyarakat mengalami perkembangan menuju cita-cita untuk maju, hidup sejahtera dan bahagia. Kegiatan proses belajar mengajar di sekolah merupakan kegiatan inti yang sangat penting. Sekolah merupakan lembaga yang mengelola dan mengatur segala potensi untuk mencapai tujuan pendidikan. Namun tidak cukup hanya sekolah yang berperan untuk untuk mewujudkan tujuan pendidikan. Kerjasama antara sekolah dengan masyarakat dan juga orangtua dengan peserta didik merupakan hal yang sangat penting. Namun tidaklah suatu hal yang mudah untuk mewujudkan itu semua, ada beberapa faktor yang dapat mempengaruhi minat belajar PAK seorang peserta didikfaktor luar maupun faktor dalam diri siswa.
\end{abstract}

Katakunci : minat belajar, pendidikan agama kristen, sekolah

\section{PENDAHULUAN}

Tumbuhnya pola pikir bahwa Pendidikan Agama Kristen yang berdasar atas Alkitab tidak relevan untuk kehidupan masa sekarang sehingga merasa tidak penting untuk belajar Pendidikan Agama Kristen merupakan hal yang keliru. Bahkan seharusnya Pendidikan Agama Kristen menjadi mata pelajaran yang paling penting untuk diajarkan disekolah.

47 | Korespondensi mengenai artikel dapat dilakukan kepada:

Lamtiur Pasaribu, STT Injili Indonesia Medan, Jl. Bunga Malem VI Km. 13 Medan Tuntungan

Email: 1mtrpasaribu@gmail.com 
Ada beberapa hal yang membuat Pendidikan Agama Kristen kurang di minati, seperti siswa merasa belajar Pendidikan Agama Kisten tidak penting karena tidak ada hubungannya dengan mata pelajaran di ujian nasional, guru juga kurang memotivasi siswa untuk kreatif dalam belajar Pendidikan Agama Kristen. Kemudian guru juga kurang profsional khusunya memafaatkan tehnologi pembelajaran sehingga belajar Pendidikan Agama Kristen membosankan, Penelitian ini juga akan menguraikan penyebab lemahnya minat belajar Pendidikan Agama Kristen dan bagiaman pengaruh guru untuk menolong sisiwa agar memiliki minat dalam belajar Pendidikan Agama Kristen. Dalam penelitian ini akan membahas faktor-faktor apa saja yg membuat siswa kurang minat belajar Pendidikan Agama kristen. Hal ini dipengaruhi faktor Internal dan faktor Eksternal yg masing-masing setiap indikator yang ada didalamnya berpengaruh terhadap tinggi rendahnya minat belajar Pendidikan Agama Kristen seorang siswa.

\section{METODE PENELITIAN}

Adapun metode penelitian yang adalah metode penelitian kualitatif. Menurut Sugiyono, mengatakan bahwa metode penelitian kualitatif adalah dapat diartikan sebagai metode penelitian yang digunakan untuk meneliti kondisi objek yang almiah, dimana peneliti berperan sebagai instrument kunci, teknik pengumpulan data dilakuka secara trianggulasi (Sugioyono, 2014). Sumber data yang dipakai dalam penelitian kualitatif berupa lingkungan alamiah. Penulis melakukan analisis data dengan memperbanyak informasi, mencari hubungan ke berbagai sumber, membandingkan, dan menemukan hasil atas dasar data sebenarnya (tidak dalam bentuk angka). Dalam tulisan ini, hasil analisis data tersebut berupa pemaparan yang berkenaan dengan judul Faktor-faktor yang mempengaruhi minat belajar Pendidikan agama Kristen di sekolah.

\section{HASIL DAN PEMBAHASAN}

\section{Pengertian Minat Belajar Pendidikan Agama Kristen}

Secara terminologis, pada frasa"minat belajar" terdapat dua istilah dan mempunyai arti masing-masing, yaitu istilah "minat" dan istilah "belajar". Minat dalam Kamus Besar Bahasa Indonesia adalah kecenderungan hati yang tinggi terhadap sesuatu, gairah atau keinginan (Pusat Bahasa, 2002). Menurut Witherington,minat 
diartikan sebagai kesadaran seseorang, bahwa suatu objek, soal atau situasi mengandung sangkut paut dengan dirinya (Witherington, 2006). Dan menurut Sadirman minat adalah suatu kondisi yang terjadi apabila seseorang melihat ciri-ciri atau arti sementara dari situasi yang dihubungkan dengan keinginan-keinginan atau kebutuhan-kebutuhan sendiri (Sadirman, 2003). Jadi "minat" merupakan sebuah dorongan hati atau sebuah penggerak yang menjadikan seseorang dengan sepenuh hati dan dengan serius menekuni atau melakukan sesuatu.

\section{Faktor-Faktor yang Mempengaruhi Minat Belajar Siswa}

Pertama, Faktor Internal. Faktor internal merupakan adanya sebuah pengaruh yang berasal dari dalam diri individu itu sendiri. Maka tinggi rendahnya minat belajar seorang siswa sangat dipengaruhi oleh faktor yang berasal dari dalam diri peserta didik tersebut, minat yang berasal dari dalam diri akan lebih berperan penting dari pada minat yang berasal dari luar diri seorang peserta didik,meskipun minat yang tumbuh dari luar (eksternal) juga penting. Di sini Ada dua faktor yang sangat mempengaruhi minat belajar seorang pesesrta didik, yakni Faktor fisiologi dan Faktor psikologis.

1. Faktor Fisiologis. Dalam mengikuti sebuah pembelajaran salah satu hal yang mempengaruhi seseorang untuk memiliki minat yang tinggi atau rendah adalah kondisi fisik Noehi mengatakan: "Kondisi Fisiologis pada umumnya sangat berpengaruh terhadap kemampuan belajar seseorang. Orang yang dalam keadaan segar jasmaninya akan berlainan belajarnya dari orang yang berada dalam kelelahan. Anak-anak yang kekurangan gizi ternyata kemampuan belajarnya dibawah anak-anak yang tidak kekurangan gizi; mereka lekas lelah, mudah mengantuk, dan sukar menerima pelajaran. Selain itu, hal yang tidak kalah penting adalah kondisi panca indera (mata, hidung, pengecap, telinga dan tubuh), terutama mata sebagai alat untuk melihat dan telinga sebagai alat untuk mendengar" (Djamarah, 2011).

Tercukupinya gizi di dalam tubuh dipengaruri dari apa yang dimakan. Irianto menjelaskan syarat makanan sehat berimbang adalah makanan yang terdapat unsurunsur seperti karbohidrat, lemak, protein, vitamin, mineral, dan air di dalamnya (Djamarah, 2011). Karena makanan yang bergizi dan bervitamin akan menambah 
vitalitas atau memberi kemampuan bagi seorang individu untuk melakukan proses belajar.

Selain itu istirahat juga penting bagi seorang peserta didik, karena sangat berpengaruh terhadap pertumbuhan dan perkembangan peserta didik tetapi terlalu banyak aktivitas fisik seperti olaraga dll, akan menimbulkan kelelahan. inilah yg membuat anak lelah dan kurang minat belajar. Sebaiknya semua seimbang, ada istirat yang cukup, makan makanan bergizi dan berolaraga teratur, makan kondisi fisik akan sehat dan siap untuk belajar

2. Faktor Psikologis. Syaiful mengatakan bahwa "Belajar pada hakikatnya adalah proses psikologi” (Djamarah, 2011). Kehadiran faktor-faktor psikologi akan memberikan kemudahan dalam upaya mencapai tujuan belajar secara optimal. Dan juga sebaliknya, tanpa kehadiran faktor-faktor psikologi, maka seorang peserta didik tidak akan bergairah dalam belajar.

Sardiman mengemukakan Pentingnya faktor-faktor psikologi sebagai berikut: "Faktor-faktor Psikologi dikatakan memiliki peranan yang sangat penting, dapat dipandang sebagai cara-cara berfungsinya pikiran siswa dalam hubungannya dengan pemahaman bahan pelajaran, sehingga penguasaan terhadap bahan yang disajikan lebih mudah dan efektif" (Sadirman, 2003).

Dengan demikian, proses belajar mengajar akan berhasil dengan baik apabila didukung oleh faktor-faktor psikologis dari sipelajar. Faktor-faktor psikologis itu antara lain:

1) Motivasi. Motivasi adalah segala sesuatu yang mendorong seseorang untuk bertindak untuk melakukan sesuatu (Purwanto, 2011). Kemudian McDonald mengatakan bahawa motivasi suatu perubahan energi yang terjadi dalam pribadi seseorang yang ditandai dengan timbulnya afektif/perasaan dan reaksi untuk mencapai tujuan (Djamarah, 2011). Dengan adanya motivasi yang kuat maka akan menjadikan minat yang kuat juga untuk tetap konsisten dalam mempelajari sesuatu. Menurut Winkel, Motivasi belajar di sekolah yang lazim itu dibedakan atas dua macam yaitu Motivasi Instrinsik dan Motivasi Ekstrinsik. Motivasi Instrinsik harus lebih utama karena tercakup dalam situasi 
belajar yang bersumber dari kebutuhan dan tujuan-tujuan dari siswa sendiri. Motivasi ini sering disebut 'motivasi murni' atau 'motivasi yang sebenarnya' yang imbul dari dalam diri peserta didik tetapi juga harus didukung dengan motivasi ekstrinsik, yaitu faktor-faktor dari luar siswa (Djamarah, 2011) dari luar ini misalnya orang tua gerja, teman dan guru di sekolah.

2) Bakat. Menurut Wijaya bakat adalah suatu kondisi pada seseorang yang memungkinkannya dengan suatu latihan khusus mencapai suatu kecakapan, pengetahuan, keterampilan khusus. Bakat adalah daya yang tersedia pada seseorang yang memungkinkan berkembangnya ciri-ciri tertentu, daya ini sudah ada sejak lahir, atau dibawa sejak lahir (Wijaya, 2007). Bakat menumbuhkan minat yang kuat untuk konsisten belajar dalam satu bidang yang dianggap seorang individu bahwa ia unggul dalam bidang tersebut. Dengan demikian, bakat melahirkan minat dan dengan menekuni bidangnya maka seorang individu akan mempunyai peluang besar untuk meraih keberhasilan pada masa mendatang. Guru Pendidikan Agama Kristen perlu melakukan pendekatan terhadap setiap peserta didik, sehingga guru tersebut dapat mengenal dan memahami pribadi peserta didik dengan baik, termasuk juga bakat yang mereka miliki. Dengan demikian, maka guru Pendidikan Agama Kristen dapat membantu setiap peserta didik untuk mengembangkan bakat mereka dalam pembelajaran Pendidikan Agama Kristen.

3) Kecerdasan. Kecerdasan merupakan faktor psikologis yang paling penting dalam proses belajar siswa, karena sangat menentukan kualitas belajar siswa. Semakin tinggi tingkat kecerdasan individu semakin besar peluang individu tersebut meraih sukses dalam belajar. Sebaliknya, semakin rendah tingkat kecerdasan individu, semakin sulit pula individu itu meraih kesuksesan belajar. Howard Gardner mengatakan ada kecerdasan Intelektual yaitu kemampuan untuk memecahkan suatu masalah yg ada dan yang baru (Surya, 2007). Berdasarkan pengertian kecerdasan tersebut, maka peserta didik akan mampu memecahkan permasalahan atau persoalan setiap materi yang dipelajari sehingga mampu untuk dipahami serta mampu memberikan sebuah kontribusi berupa pertanyaan yang dapat membantu para peserta didik lebih mendalami dan memahami materi pembelajaran secara baik, maka dengan kecerdasan 
tersebut, peserta didik akan mendapat sebuah keberhasilan dalam proses belajar. Memang keberhasilan belajar tidak hanya ditentukan oleh kecerdasan intelektual saja. Jejen Musfah mengatakan ada kecerdasan lain yang lebih penting daripada kecerdasan Intelektual yaitu kecerdasan emosional dan kecerdasan spritual (Musfah, 2015). Keceradasan yang terpenting adalah kecerdasan spiritual, seperti yang ditulis dalam Jejen Musfah, bahwa melalui kecerdasan spiritual setiap individu akan difasilitasi untuk mengatasi persoalan hidup dan berdamai dengan persoalan itu, memiliki tingkat kesadaran yang tinggi, mampu mengambil pelajaran yang berharga dari sebuah kegagalan, mampu mewujudkan hidup sesuai dengan visi dan misi, serta pada akhirnya membuat seseorang mengerti akan makna hidupnya (Musfah, 2015). Oleh sebab itu, sangatlah penting bagi seorang peserta didik memiliki kecerdasan Spiritual, karena kecerdasan tersebutlah yang akan mewujudkan visi dan misi kehidupan, artinya kecerdasan spiritual meransang peserta didik untuk giat belajar agar mereka mampu untuk mencapai setiap visi-misi dalam kehidupan mereka. Pendidikan Agama Kristen adalah sebuah pembelajaran yang mampu meningkatkan ke tiga kecerdasn itu, sehingga tidak salah apabila Pendidikan Agama Kristen menjadi sebuah pelajaran yang terpenting dalam sekolah dan di minati oleh peserta didik.

Kedua, Faktor Eksternal. Tumbuhnya minat belajar individu juga dapat dipengaruhi oleh keadaan luar seperti dari keluarga atau orang tua, sekolah dan masyarakat.

1. Faktor dari Keluarga. Keluarga mempunyai pengaruh yang begitu kuat dalam pendidikan anak. Menurut Hasbullah, keluarga merupakan persekutuan hidup dimana anak menjadi diri pribadi. Keluargalah yang menyiapkan potensi pertumbuhan dan pembentukan kepribadian anak (Hasbullah, 2012). Setiap orangtua Kristen tentu menginginkan hasil belajar Pendidikan Agama Kristen anak sangat memuaskan, karena itu peran orangtua dalam menumbuhkan minat belajar Pendidikan Agama Kristen anak sangatlah berpengaruh. Seperti yang diungkapkan oleh Homrighausen, bahwa Pendidikan Agama Kristen berlandaskan pada keluarga 
Kristen adalah pemberian daripada Tuhan yang tidak ternialai harganya, keluarga Kristenlah yang memegang peranan penting dalam Pendidikan Agama Kristen (Enklaar, 2010). Menurut Dalyono, faktor orang tua dalam keluarga sangat besar pengaruhnya terhadap keberhasilan belajar anak. Tinggi rendahnya pendidikan orang tua, besar kecilnya penghasilan, cukup atau kurang perhatian dan bimbingan orang tua, rukun atau tidaknya orang tua, akrab atau tidaknya orang tua dengan anak-anak, tenang atau tidaknya situasi rumah, semua itu turut mempengaruhi pencapaian belajar anak.

Dalam lingkungan keluarga sendiri banyak faktor yang dapat memengaruhi minat belajar seorang anak, seperti yang diungkap oleh Syah, bahwa Orang tua atau keluarga siswa merupakan lingkungan sosial yang lebih banyak mempengaruhi kegiatan belajar anak. Sifat-sifat orang tua, praktik pengelolaan keluarga, ketegangan keluarga, dan demografi keluarga (letak rumah). Semua itu memberi pengaruh terhadap kegiatan belajar dan hasil yang dicapai oleh siswa (Syah, 2008). Maka dari itu cara orang tua mendidik anaknya harus diperhatikan dengan baik karena berpengaruh besar terhadap belajar anaknya. Hal ini sejalan dengan pendapat Slameto, yang menyatakan: Orang tua yang kurang / tidak memperhatikan pendidikan anaknya, misalnya mereka acuh tak acuh terhadap belajar anaknya, tidak memperhatikan sama sekali kepentingankepentingan dan kebutuhan-kebutuhan anak dalam belajar, tidak mengatur waktu belajarnya, tidak menyediakan/ melengkapi alat belajarnya, tidak memperhatikan apakah anak belajar atau tidak, tidak mau tahu bagaimanakah kemajuan belajar anaknya, kesulitan-kesulitan yang dialami dalam belajar dan lain-lain, dapat menyebabkan anak tidak/ kurang berhasil dalam belajarnya (Syah, 2008).

Mendidik anak dengan cara yang terlalu keras, seperti memaksa untuk belajar, merupakan cara mendidik yang juga salah karena anak akan diliputi rasa keterpaksaandan akhirnya tidak mau belajar bahkan jika rasa keterpaksaan itu semakin serius akan mengakibatkan anak tertekan kejiwaannya. Maka dari itu, cara mendidik anak dengan cara yang baik harus dimengerti oleh setiap orang tua.Seperti tertulis dalam kitab Efesus: Dan kamu, bapa-bapa, janganlah bangkitkan amarah didalam hati anakmu, tetapi didiklah mereka didalam ajaran dan nasihat Tuhan dalam Efesus 6:4 (Alkitab, 2006). 
Sebagai orang tua Kristen menjadi hal penting untuk mendidik anak belajar Pendidikan Agama Kristen, dan juga perlu memperhatikan anak dalam belajar Pendidikan Agama Kristen di sekolah, dengan cara menanyakan kembali materi pembelajaran Pendidikan Agama Kristen yang telah dipelajari disekolah, lalu membahas ulang bersama dengan orang tua dan mendukungnya juga dalam kesehariannya seperti berdoa bersama keluarga dirumah dan membawa anak aktif mengikuti ibadah sekolah minggu.

2. Faktor dari Sekolah. Lingkungan sekolah yang baik dapat mendorong siswa untuk belajar lebih giat. Sekolah secara sistematis melaksanakan program bimbingan, pengajaran, dan latihan dalam rangka membantu siswa agar mampu mengembangkan potensinya baik yang menyangkut aspek moral, spiritual, intelektual, emosional, maupun sosial. Menurut Nana, lingkungan sekolah merupakan: lingkungan kedua setelah lingkungan keluarga karena apa yang sudah ditanamkan dalam keluarga akan dilanjutkan pada lingkungan sekolah. Pengetahuan, nilai-nilai dan keterampilan yang diberikan di sekolah merupakan kelanjutan dari apa yang diberikan di dalam keluarga tetapi tingkatannya lebih tinggi dan lebih kompleks.Pendidikan di sekolah lebih bersifat formal karena di sekolah terdapat kurikulum sebagai rencana pendidikan danpengajaran, guru-guru yang lebih profesional, sarana dan prasarana serta fasilitas sebagai penunjang proses pendidikan (Sukmadinata, 2004).

Senada dengan pendapat tersebut, Hasbullah menyatakan bahwa "pada dasarnya pendidikan disekolah merupakan bagian dari pendidikan dalam keluarga, yang sekaligus juga merupakan lanjutan dari pendidikan dalam keluarga. Disamping itu, kehidupan disekolah merupakan jembatan bagi anak yang menghubungkan kehidupan dalam keluarga dengan kehidupan dalam masyarakat kelak" (Syah, 2008) Sekolah merupakan lembaga pendidikan formal pertama yang sangat penting dalam menentukan keberhasilan belajar siswa. Lingkungan sekolah yang baik dapat mendorong siswa untuk belajar lebih giat. Sekolah secara sistematis melaksanakan program bimbingan, pengajaran, dan latihan dalam rangka membantu siswa agar mampu mengembangkan potensinya baik yang menyangkut aspek moral, spiritual, intelektual, emosional, maupun sosial melalui mata pelajaran tertentu. Lingkungan 
sekolah yang baik adalah lingkungan yang menunjang proses pembelajaran berjalan dengan lancar. Menurut Ihsan, tugas sekolah sangat penting dalam menyiapkan anakanak untuk kehidupan anak-anak untuk kehidupan masyarakat. Sekolah semata-mata bukan sebagai konsumen, tetapi juga ia sebagai produsen dan pemberi jasa yang sangat erat hubungannya dengan pembangunan (Ihsan, 2011). Oleh karena itu, sekolah harus menjaga agar kondisi lingkungan baik itu lingkungan fisik maupun lingkungan sosial berjalan dengan baik. Seperti yang diungkapkan oleh Nana, bahwa lingkungan sekolah memegang peranan penting bagi perkembangan belajar para siswa. Lingkungan ini meliputi lingkungan fisik sekolah seperti lingkungan kelas, sarana dan prasarana belajar yang ada, sumber-sumber belajar dan media belajar. Selain lingkungan fisik yang termasuk dalam lingkungan sekolah adalah lingkungan sosial menyangkut hubungan siswa dengan teman-temannya, guru-gurunya, serta staf sekolah yang lain. Lingkungan sekolah juga menyangkut lingkungan akademis, yaitu sarana dan pelaksanaan kegiatan belajar mengajar, berbagai kegiatan kokurikuler, dan lain sebagainya (Ihsan, 2011). Hal yang sama juga diungkapkanoleh Dalyono, bahwa kualitas guru, metode mengajarnya, kesesuaian kurikulum dengan kemampuan anak, keadaan fasilitas atau perlengkapan di sekolah, keadaan ruangan kelas maupun praktik, jumlah murid per kelas, pelaksanaan tata tertib sekolah dan sebagainya turut mempengaruhi keberhasilan belajar anak (Dalyono, 2009).

Maka berdasarkan pendapat oleh beberapa ahli tersebut, maka ada beberapa faktor dari lingkungan sekolah yang perlu untuk diperhatikan untuk menunjang tumbuhnya minat belajar Pendidikan Agama Kristen yang tinggi bagi peserta didik. dan sekolah sebaiknya juga berperan untuk meningkatkan minat belajar Pendidikan Agama Kristen: Pertama, Guru Pendidikan Agama Kristen. Profesi guru, terkhusus guru Pendidikan Agama Kristen merupakan sebuah panggilan dari Allah, maka guru Pendidikan Agama Kristen harus menaruh komitmennya menjadi seorang guru Pendidikan Agama Kristen yang profesional. seperti yang di ungkapkan oleh Homrighousen dan Enklaar, bahwa guru harus sadar profesi itu datangnya dari Allah, dan guru PAK adalah hamba yang diutus Allah, oleh sebab itu guru PAK harus menganggap keguruannya adalah sangat penting, melakukan tugasnya mendidik secara serius dan sampai tuntas (Simanjuntak, 2019). Guru Pendidikan Agama Kristen merupakan oknum utama yang berperan dalam pertumbuhan minat 
belajar Pendidikan Agama Kristen peserta didik. Guru Pendidikan Agama Kristen merupakan suatu pekerjaan profesional. Menurut Nana, untuk dapat melaksanakan tugasnya dengan baik guru harus memiliki ilmu dan kecakapan keterampilan keguruan. Agar mampu menyampaikan ilmu pengetahuan di bidang studi yang diajarkannya guru harus menguasai ilmu atau bidang studi tersebut secara mendalam dan meluas (Sukmadinata, 2004). Dan tidak hanya berhenti dalam menyampaikan ilmu, guru Agama Kristen juga harus mengajak peserta didik agar dapat mengaplikasikan setiap materi pelajaran dalam kehidupan sehari-hari dan dalam pelayanan.

Benar bahwa bahan pelajaran sangat menentukan minat peserta didik untuk belajar.bahan pelajaran yang diminati siswa akan sering dipelajari siswa yang bersangkutan. Begitu juga sebaliknya apabila bahan pelajaran tidak diminati oleh siswa maka akan mudah diabaikan oleh siswa. Disinilah guru Pendidikan Agama Kristen berperan penting karena guru yang disenangi oleh siswa dapat menimbulkan semangat belajar siswa,meskipun bahan pelajaran yang dipelajari sebenarnya kurang menarik bagi siswa namun dengan kehadiran guru yang disenangi oleh peserta didik, para peserta didik akan menaruh semangat untuk mengikuti prosees belajar mengajar Pendidikan Agama Kristen.

Demikian juga sebaliknya, guru Pendidikan Agama Kristen yang sangat membosankan dan tidak profesional justru menumbuhkan rasa jenuh dalam mengikuti proses belajar, sehingga dapat mengakibatkan kemalasan mengikuti proses belajar mengajar bagi peserta didik bahkan sekalipun bahan pelajaran Pendidikan Agama Kristen tersebut disenangi oleh siswa.

Kedua, Media Pembelajaran.Seorang guru Pendidikan Agama Kristen dituntut untuk tidak buta dalam penggunaan media belajar, seperti Alkitab, alam sekitar, bahkan alat elektronik yang dapat memperlancar proses belajar mengajar seperti laptop dan LCD yang dapat menjadi media Audio visual.Karena Media pembelajaran bermanfaat untuk melibatkan siswa secara nyata melalui aktifitas dan pikiran mereka, seperti yang diungkapkan oleh Arief bahwa: 
Media berfungsi untuk tujuan instruksi dimana informasi yang terdapat dalam media itu harus melibatkan siswa baik dalam benak atau mental maupun dalam bentuk aktivitas yang nyata sehingga pembelajaran dapat terjadi. Materi harus dirancang secara lebih sistematis dilihat dari segi prinsip-prinsip belajar agar dapat menyiapkan instruksi yang efektif. Disamping menyenangkan, media pembelajaran harus dapat memberikan pengalaman yang menyenangkan dan memenuhi kebutuhan perorang siswa (Sadiman, 2013).

Penggunaan media-media pembelajaran akan menghilangkan proses belajar mengajar secara monoton dan membosankan, dengan penggunaan media pembelajaan peserta didik akan lebih cepat memahami materi pembelajaran, seperti contoh dalam pembelajaran Pendidikan Agama Kristen, apabila materi yang disampaikan adalah tentang penciptaan, guru dapat menggunakan media alam agar secara langsung dapat dilihat sehingga mudah dimengerti oleh peserta didik,atau materi tentang perjalanan kehidupan Yesus Kristus, guru Pendidikan Agama Kristen dengan kreatifnya dapat memutar video dari laptop dengan bantuan lcd agar dapat dilihat oleh seluruh peserta didik, sehingga peserta didik tidak hanya mendengar cerita dari guru Pendidikan Agama Kristen.

Maka dengan penggunaan media pembelajaran secara kreatif oleh guru Pendidikan Agama Kristen, Peserta didik akan selalu bersemangat dan menaruh minat untuk belajar Pendidikan Agama Kristen. Seperti yang diungkapkan oleh Hamalik bahwa pemakaian media pembelajaran dalam proses belajar mengajar dapat membangkitkan keinginan minat baru, membangkitkan motivasi dan ransangan kegiatan belajar, dan bahkan membawa pengaruh-pengaruh psikologis terhadap siswa (Hamalik, 2014).

Ketiga, Sarana dan Prasarana.Selanjutnya dari faktor sekolah adalah sarana dan prasarana, menurut Daryanto, sarana dan prasarana secara Etimologi "bahwa sarana belajar adalah alat langsung untuk mencapai tujuan pendidikan, misalnya lokasi/tempat, bangunan dan lain-lain, sedangkan prasarana adakah alat yang tidak langsung untuk mencapai tujuan pendidikan, misalnya ruang, buku, perpustakaan, laboratorium dan sebagainya" (Daryanto, 2008).

Berdasarkan pengertian tersebut dapat disimpulkan bahwa kelengkapan sarana prasarana adalah fasilitas yang digunakan untuk menunjang kegiatan belajar demi mencapai tujuan pendidikan. Maka dari itu dalam mencapai tujuan dari Pendidikan 
Agama Kristen, sarana dan prasarana tidak dapat diabaikan, seperti kelengkapan fasilitas belajar Pendidikan Agama Kristen, yaitu buku materi dan Alkitab, serta bukubuku Kristen yang semestinya tersedia dalam perpustakaan. Dengan kelengkapan fasilitas belajar Pendidikan Agama Kristen, maka peserta didik akan lebih bersemangat dan memiliki pertumbuhan minat belajar Pendidikan Agama Kristen.

3. Faktor dari Masyarakat. Partisipasi masyarakat dalam pendidikan di sekolah merupakan suatu keharusan. Kepedulian, perhatian, bantuan, dan dukungan masyarakat merupakan upaya untuk meningkatkan mutu pendidikan. Dengan keterlibatan masyarakat, sekolah mendapatkan manfaat dalam mewujudkan kualitas pendidikan. Masyarakat merupakan lembaga pendidikan yang ketiga setelah pendidikan di lingkungan keluarga dan di lingkungan sekolah.

Jika dilihat dari ruang lingkup masyarakat banyak dijumpai keanekaragaman bentuk dan sifat masyarakat yang dapat memperkaya budaya bangsa Indonesia.Dan lingkungan masyarakat juga mempengaruhi minat belajar Pendidikan Agama Kristen peserta didik. Seperti yang di ungkapkan oleh Slameto bahwa: Bentuk kehidupan masyarakat Kehidupan masyarakat di sekitar siswa juga berpengaruh terhadap belajar siswa. Masyarakat yang terdiri dari orang-orang yang tidak terpelajar, penjudi, suka mencuri, dan mempunyai kebiasaan tidak baik akan berpengaruh buruk pada siswa yang berada disitu. Karena siswa tertarik untuk ikut berbuat seperti yang dilakukan orangorang yang ada di sekitarnya. Sehingga semangat dan proses belajar siswa terganggu karena perhatiannya yang semula terpusat pada pelajaran berpindah keperbuatanperbuatan yang selalu dilakukan orang-orang di sekitarnya tadi. Sebaliknya, jika lingkungan siswa adalah orang-orang yang terpelajar, mereka mendidik dan menyekolahkan anak-anaknya antusias dengan cita-cita yang luhur akan masa depan anaknya, siswa cenderung terpengaruh juga ke hal-hal yang dilakukan orang-orang di lingkungannya. Pengaruh tersebut dapat mendorong siswa belajar lebih giat lagi (Slameto, 2010).

Maka dari itu, orang tua peserta didik perlu untuk memperhatikan cara hidup masyarakat sekitar dimana anak mereka akan bertumbuh dan berkembang. Selain dari pada itu, beberapa indikator faktor dari masyarakat adalah sebagai berikut: 
1) Kegiatan Kerohanian. Kegiatan rohani menjadi salah satu faktor untuk mengingkatkan minat belajar Pendidikan Agama Kristen, sangat baik apabila peserta didik aktif untuk mengukuti setiap kegiatan-kegiag diselenggarakan oleh gereja dalam masyarakat. Dasar dari mengikuti kegiatanrohani adalah membantu kesadaran dan perhatian untuk membawa seorang yang muda untuk memiliki pengalaman rohani dan menjadi pribadi yang bersaksi dalam tindakan dan kata-kata. Pembimbing harus mendorong dan memotivasi pemuda untuk meningkatkan minat sebagai sarana dalam meningkatkan kedewasaan mereka (SJ, 2006). Jadi untuk menigkatkan minat belajar pendidikan Agama Kristen, peserta didik sangat diharapkan agar mengikuti setiap kegiatan-kegiatan Rohani yang ada, baik itu dalam keluarga, dalam masyarakat, dalam gereja, maupun dalam sekolah. Maka dengan mengikuti setiap kegiatan-kegiatan tersebut, peserta didik akan semakin meningkat minat belajar Pendidikan Agama Kristennya, dan terlebih-lebih peserta didik akan semakin dewasa kerohaniannya. Adapun Kegiatan Kemasyarakatan dalam pembelajaran Pendidikan Agama Kristen seperti gotong royang dan gerakan kebersihan desa, dan sebagainya yang mendukung proses belajarnya di sekolah. Di sinipeserta didik akan didorong untuk aktif dalam bersosialisasi dengan masyarakat, dan menjadi bagian masyarakat yang baik. Mengabil bagian dalam kegiatan masyarakat di luar sekolah, itu juga baik, namun harus di batasi karena terlalu aktif dalam semua kegiatan kemasyarakatan juga dapat menganggu proses belajar peserta didik disekolah. Pendapat tersebut senada dengan ungkapan Slameto bahwa kegiatan siswa dalam masyarakat dapat menguntungkan pribadinya. Tetapi jika siswa terlalu banyak mengambil bagian dalam kegiatan kemasyarakatan, dimungkinkan akan dapat menggangu proses belajarnya disekolah. Sehingga perlu adanya batasan kegiatan siswa diluar sekolah agar tugas utamanya sebagai siswa yaitu sebagai siswa dapat berjalan dengan lancar (Slameto, 2010). Maka dari itu, peserta didik juga harus tahu kegiatan apa saja yang perlu baginya untuk aktif dalam kegiatan kemasyarakatan.

2) Media Massa. Media massa pada jaman ini telah dikenal akrab oleh anak-anak, keseharian anak dengan SmartPhone misalnya, melalui media massa tersebut banyak hal yang dapat ditemui oleh anak, seperti halnya mencari sumber pembelajaran dan dapat membantu anak mengerjakan tugas mereka, Slameto juga mengungkapkan bahwa media massa merupakan salah satu media untuk belajar siswa. Media massa 
yang baik akan memberikan pengaruh yang baik terhadap proses belajar siswa. Diperlukan kontrol dari semua pihak karena belakangan ini banyak media massa yang kurang tepat dikonsumsi oleh siswa, baik dari orang tua, guru, dan lingkungan masyarakat (Slameto, 2010).

Media massa memang sangat berguna dan sangat membantu peserta didik untuk mengalami proses belajar, namun tanpa perhatian dari orang tua, guru dan masyarakat, media massa dapat berdampak negatif juga terhadap anak. Apabila media massa dipergunakan dengan baik, maka minat belajar Pendidikan Agama Kristen peserta didik juga akan semakin tinggi, karena mereka akan dengan mudah mencari refrensi lain sebagai sumber bahan belaajar mereka. Namun sebaliknya, apabila media massa digunakan oleh anak, namun tidak diperhatikan dengan baik, maka akan berdampak buruk terhadap minat belajar Pendidikan Kristen peserta didik, mereka akan cenderung kecanduan bermain game, dam memiliki pikiran jorok akibat konten yang tidak wajar bagi seorang peserta didik.

3) Teman Sepergaulan. Slameto berpendapat bahwa "agar siswa dapat belajar dengan baik, maka perlu diusahakan agar siswa memiliki teman bergaul yang baik. Pembinaan dan pengawasan dari orang tua, guru, dan masyarakat harus dilakukan dengan bijak" (Slameto, 2010). Berdasarkan pemaparan diatas, lingkungan masyarakat merupakan faktor yang kuat dalam pengaruh bertumbuhnya sikap seorang individu, karena seorang individu akan bertumbuh sesuai dengan lingkungan tempat ia tinggal dan bergaul. Apabila seorang peserta didik bergaul dengan speserta didik lainnya yang menaruh minat belajar yang tinggi terhadap Pendidikan Agama Kristen, maka peserta didik tersebut juga akan terpengaruh. Demikian juga sebaliknya, apabila seorang peserta didik memiliki teman sepergaulan yang tidak baik, maka pengaruh yang diberikan adalah pengaruh yang sama sekali tidak membangun minat belajar Pendidikan Agama Kristen peserta didik tersebut. Seperti yang tertulis dalam Alkitab bahwa: Pergaulan yang buruk merusak kebiasaan yang baik dalam 1 Korintus 15:33 (Alkitab, 2006). 


\section{KESIMPULAN DAN SARAN}

Adapun kesimpulan dari pembahasan diatas bahwa terdapat dua faktor yang mempengaruhi, yaitu faktor Internal dan faktor Eksternal. Pertama, indikator pertama dari faktor internal adalah fisiologi. Kebutuhan fisiologis terdiri dari makan, istirahat dan latihan atau olah raga. Faktor tersebut harus diperhatikan dengan baik karena berpengaruh terhadap minat belajar PAK peserta didik. Kondisi tersebut dapat dilakukan dengan pola makan yang teratur dan tidak sembarangan karena gizi yang baik akan mempengaruhi tumbuh kembang dan daya nalar anak. Indikator selanjutnya dari faktor internal adalah faktor psikologi. Psikologi tersebut mencakup motivasi, bakat dan kecerdasan. Setiap peserta didik membutuhkan motivasi untuk menggerakkan mereka melakukan sesuatu. Motivasi sendiri dapat berasal dari diri peserta didik bahkan dari luar diri peserta didik, jika motivasi anak kuat untuk belajar PAK, maka akan diikuti secara otomatis minat belajar PAK peserta didik juga tinggi. Bakat yang dimiliki anak dapat dikembangkan. Jika bakat anak dapat dikembangkan melalui belajar PAK, maka minat belajar PAK peserta didik akan semakin bertumbuh. Dan kecerdasan, terkhusus kecerdasan spiritual. Apabila peserta didik memiliki kecerdasan spiritual yang kuat, maka peserta didik akan mencoba membangun hubungan dengan Allah lebih dekat lagi. Dengan demikian maka kecerdasan spiritual dapat munumbuhkan minat belajar PAK peserta didik.

Kedua, selanjutnya adalah faktor eksternal yaitu a faktor dari keluarga. Keluarga begitu sangat penting dan sangat berpengaruh terhadap minat belajar PAK peserta didik. Orangtua adalah orang yang sangat memungkinkan untuk meningkatkan minat belajar PAK peserta didik. Jadi orangtua harus mendukung peserta didik dalam belajar PAK demi meningkatkan minat belajar PAK mereka.

Ketiga, Indikator selanjutnya dari faktor eksternal yaitu faktor dari sekolah. Yang perlu diperhatikan adalah Guru PAK seharusnya mengenal dengan baik setiap peserta didik. Mengenal dalam arti memahami kepribadian mereka, mengetahui bagimana latar belakang mereka, mengetahui bakat mereka. Dan guru PAK haruslah mampu mengajar dengan baik dan menarik, serta mengunakan Media pembelajaran. Kelengkapan dan kenyamanan sarana dan prasarana sekolah. Maka apabila demikian, peserta didik akan menaruh minat lebih lagi untuk belajar PAK. 
Keempat, indikator terakhir dari faktor eksternal adalah faktor dari masyarakat kegiatan masyarakat, karena demikianlah yang dituntut oleh PAK, bahwa setiap orang Kristen harus hidup rukun. Selanjutnya adalah media sosial. Media sosial telah merambat kedalam setiap kalangan, bahkan kalangan peserta didik. Setiap berita dipertunjukkan ke setiap masyarakat segala golongan dengan sangat terbuka. Peserta didik harus dikontrol dalam menggunakan media sosial, karena dapat berdampak buruk. Namun jika diawasi oleh orangtua, guru dan syarakat, maka pengguanaan media sosial dapat meningkatkan minat belajar Pendidikan Agama Kristen. Terakhir adalah teman sepergaulan. Teman sepergaulan berpengaruh terhadap minat belajar PAK peserta didik. Teman yang suka belajar akan meningkatkan minat belajar peserta didik. Sebaliknya, teman yang tidak mementingkan belajar akan membawa minat belajar PAK peserta didik menurun.

\section{DAFTAR PUSTAKA}

Alkitab. (2006). Alkitab. Lembaga Alkitab Indonesia.

Dalyono. (2009). Psikologi Pendidikan. Rineka Cipta.

Daryanto, H. M. (2008). Administrasi Pendidikan. Rineka Cipta.

Djamarah, S. B. (2011). Psikologi Belajar. Rineka Cipta.

Enklaar, E. G. H. dan I. H. (2010). Pendidikan Agama Kristen. BPK Gunung Mulia.

Hamalik, O. (2014). Kurikulum dan Pembelajaran. Bumi Aksara.

Hasbullah. (2012). Dasar-dasar Ilmu Pendidikan. PT. Raja Grafindo Persada.

Ihsan, H. F. (2011). Dasar-Dasar Kependidikan. Rineka Cipta.

Musfah, J. (2015). Managemen Pendidikan: Teori, Kebijakan dan Praktik. Kencana.

Purwanto, N. (2011). Psikologi Pendidikan. Rosda Remaja Karya.

Pusat Bahasa, D. P. N. (2002). Kamus Besar Bahasa Indonesia (Edisi Keti). Balai Pustaka.

Sadiman, A. S. (2013). Media Pendidikan: Pengertian, Pengembangan dan Pemanfaatannya. CV. Rajawali.

Sadirman, A. M. (2003). Interaksi Motivasi Belajar Mengajar. PT. Grafindo Persada.

Simanjuntak, D. M. (2019). Diktat Kuliah: Pembimbing PAK.

SJ, M. C. dan S. (2006). Menuju Kedewasaan Kristen. Kanisius.

Slameto. (2010). Belajar dan Faktor-faktor yang Mempengaruhinya. Rineka Cipta.

Sugioyono. (2014). Metode Penelitian Manajemen. Alfa Beta. 


\section{JURNAL CHRISTIAN HUMANIORA}

Vol.5, No.1, Mei 2021, pp. 47-63 p-ISSN: 2598-6317- e-ISSN: 2599-1965

Sukmadinata, N. S. (2004). Landasan Psikologi Proses Pendidikan. PT. Remaja Rosdakarya.

Surya, S. (2007). Melejitkan Multiple Intelegences Sejak Dini. ANDI OFFSET.

Syah, M. (2008). Psikologi Belajar. PT. Raja Grasido Persada.

Wijaya, J. (2007). Psikologi Bimbingan. PT. Eresco.

Witherington, H. C. (2006). Psikologi Pendidikan. Aksara Baru. 